\title{
Gender, sexuality, and transformation: making historical sense of contemporary public health dilemmas
}

\section{Commentary}

Given that so many of the public health challenges facing the human population around the globe are bound up with gender based inequalities, we believe it is important for all policy makers and researchers to understand that the expectations placed on women and men today are not timeless or given. ${ }^{1}$ Both men and women need to know that women have not always been the weaker, less socially powerful sex. There is a rich diversity of cultures across the world and throughout history where women and men have shared. ${ }^{2,3}$ Before the agricultural revolution and creation of marriage and private property, during a time when lineage was traced through mothers and grandmothers, cave art and tiny figurines revealed the veneration off eminine sexuality. ${ }^{4,5}$ All adults worked collectively to hunt and gather food and care for children. Yet this changed for most humans after we began to settle in one place, plant crops and domesticate animals. Understanding this transition, in our diet, our social structures and particularly our systems of assigning meaning to gender, is essential to strategizing well about contemporary public health challenges.

After humans transitioned from hunting and gathering into larger agricultural communities, between 8,000 - 3,000 BCE across most areas of the planet, social organizations based on hierarchy, patrilineal inheritance, a warrior caste, and worship of male gods, all emerged. Doing what was good for the community or wider web of life became less important than serving the gods and the king in battle. Conquest brought slaves, the earliest form of capital, and societies with large slave populations always end up with one set of rules for conquerors and another for the conquered. The creation of private property and inherited titles led men to want to sire heirs to whom they could pass on their name, their power, and their wealth.

To make sure "their woman" did not become pregnant by any other man, the warrior-priest rulers of ancient times created legal and religious structures that insisted on monogamy, at least for elite women. The new rules restricted women's lives, and condoned violence against women and "lesser men." The whip and the sword have often enforced the resulting hierarchy of masculinities, with powerful men mobilizing other men's violence to maintain their control. Among dominant groups, boys and men have been taught to be tough, supposedly to be more powerful, but in actuality, to serve the interests of a powerful few men at the top. ${ }^{6}$ Girls and women in such systems are told to be good and obedient, to focus on being a wife and mother. For thousands of years, we've been sold on the idea that these ancient stereotypes are normal, and natural.

Yet across the world today, in many ways and in many cultures, the open use of violence by powerful men is being challenged by human rights, feminist, queer, and other campaigners. From marriages to dictatorships, the rule of the 'big man' and his ability to hurt others is in question. Despite living through a period of political and social transformation, contemporary-and often unconscious-ideas about how

\author{
Volume 4 Issue 5 - 2016
}

\author{
Betsy Crane,' Jesse Crane Seeber ${ }^{2}$ \\ 'Widener University, USA \\ ${ }^{2}$ North Carolina State University, USA
}

Correspondence: Betsy Crane,Widener University, Chester, Pennsylvania, USA, Email bcrane@widener.edu

Received: August 12, 2016 | Published: September 02, 2016

we are supposed to be and act often depend on gender expectations handed down from ancient cultures. Conflicts about gender and sexuality are playing out differently in different societies, with some seeing efforts to advance women's or queer rights as 'westernization,' while other communities bemoan the impact of western experts and their attempts to 'develop' indigenous communities. There is no simple or singular story here, but thousands of stories around the world. Despite the evidence of history and real diversity, all too often, people still believe that men and women are from two different planets, as if nature determines our behavior. While biology has a role in shaping our experiences, the gender constrictions imposed by religious and civic laws are not natural or inevitable. ${ }^{8}$ Instead, what has been called "the war between the sexes" is the product of social and political forces. Yet, neither men nor women are to blame for this history or the institutions that seek to naturalize it. Instead we can all benefit from understanding how we ended up with the problems we have, and what we can do to address them.

Without such reflection, it is too easy to believe the cave man myth, that boorish men once attacked whatever woman they wanted, based on a biologically based tendency towards rape. Evolutionary biologists oddly reinforce this cartoon image. ${ }^{9}$ Arguing that nature is destiny, they observe that women are limited in the number of offspring they can have, while men can impregnate as many women as they want. On the basis of these observations, they assume that hunter-gatherers led lives that were brutish and short. Every woman, they assert, needed to have a 'tough guy' or 'protector' to care for her and her offspring. Do we really believe that such men would last very long in grandmother clans, ${ }^{3,10}$ consisting of mothers, their daughters and sisters, and the men invited to join them? The evolutionary biology narratives presume a consistent social order that cross-cultural and historical evidence strongly disputes. ${ }^{3}$ Boys and men in various times, places, and communities have been so different that the tired cliché of "boys will be boys" falls apart. Instead, it can be argued that current gender stereotypes and pressures are based on the historical/cultural evolution of our species, rather than being determined by genetics. ${ }^{1}$ 
We invite readers to grapple with the ways that people of all genders are hurt by continued inequalities that shape fantasies and politics, emotions and bodies. Change is occurring, given ongoing transformations based on the human rights framework, post-colonial awareness, anti-racism, feminism, gay liberation, and emerging transgender identities. We can shed the constraints that keep everyonemen and women, gay and straight, cis- and transgender caught in gendered boxes that just don't fit. Our history of inequalities need no longer limit our present and future lives. Both historical and crosscultural reflection make it clear that our lives and relationships can be so much better for people of all genders than ancient prejudices, many still evident today, might admit.

\section{Acknowledgements}

None.

\section{Conflict of interest}

The author declares no conflict of interest.

\section{References}

1. Crane- Seeber Jesse, Betsy Crane. Contesting essentialist theories of patriarchal relations: an antidotal history of gender. Journal of Men's Studies. 2010;18(3):218-237.
2. Marler, Joan. The myth of universal patriarchy: a critical response to Cynthia Eller's myth of matriarchal prehistory. Feminist Theology. 2006;14(2):163-187.

3. Sandy, Peggy Reeves. The socio-cultural context of rape: A crosscultural study. Journal of Social Issues. 1981;37(4):5-27.

4. Eisler Riane Tennenhaus. The chalice and the blade: Our history, our future. 1st ed. USA: Harper \& Row; 1987.

5. Gimbutas, Marija Alseikaitçe. The goddesses and gods of old Europe, 6500-3500 BC, myths and cult images. New and updated ed. USA: University of California Press; 1982.

6. Connell, Raewyn. 100 Million Kalashnikovs: Gendered power on a world scale. Debate Feminista. 2016;51:3-17.

7. Crane, Betsy, Jesse Crane-Seeber. The four boxes of gendered sexuality: Good girl/bad girl and tough guy/sweet guy. In: Heasley R, et al. editors. In Sexual Lives: A Reader on the Theories and Realities of Human Sexuality. USA: McGraw-Hill; 2003.

8. Jesse Crane-Seeber, Betsy Crane. What does evolution have to do with legal enclaves? Politics \& Gender. 2013:100-105.

9. Mc Caughey, Martha. The Caveman Mystique: Pop-Darwinism and the Debates Over Sex, Violence, and Science. London: Routledge, Taylor and Francis; 2008.

10. Sjoo M, Mor B. The Great Cosmic Mother: Rediscovering the Religion of the Earth. USA: Harper \& Row; 1991. 